\title{
ZOOTAXA
}

2703

\section{Crab spiders from Xishuangbanna, Yunnan Province, China (Araneae, Thomisidae)}

\author{
GUO TANG ${ }^{1,2} \&$ SHUQIANG LI ${ }^{1,3}$ \\ ${ }^{1}$ Institute of Zoology, Chinese Academy of Sciences, Beijing 100101, China \\ ${ }^{2}$ College of Life Sciences, Hunan Normal University, Changsha 410081, China \\ ${ }^{3}$ Corresponding author: lisq@ioz.ac.cn
}

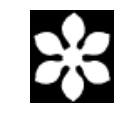

Magnolia Press

Auckland, New Zealand 
GUO TANG \& SHUQIANG LI

Crab spiders from Xishuangbanna, Yunnan Province, China (Araneae, Thomisidae)

(Zootaxa 2703)

105 pp.; $30 \mathrm{~cm}$.

3 Dec. 2010

ISBN 978-1-86977-623-7 (paperback)

ISBN 978-1-86977-624-4 (Online edition)

\section{FIRST PUBLISHED IN 2010 BY}

Magnolia Press

P.O. Box 41-383

Auckland 1346

New Zealand

e-mail: zootaxa@mapress.com

http://www.mapress.com/zootaxa/

(C) 2010 Magnolia Press

All rights reserved.

No part of this publication may be reproduced, stored, transmitted or disseminated, in any form, or by any means, without prior written permission from the publisher, to whom all requests to reproduce copyright material should be directed in writing.

This authorization does not extend to any other kind of copying, by any means, in any form, and for any purpose other than private research use.

ISSN 1175-5326 (Print edition)

ISSN 1175-5334 (Online edition) 


\section{Table of contents}

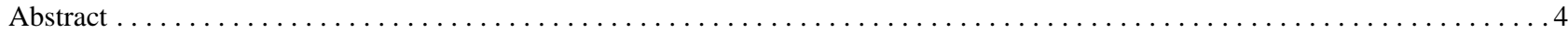

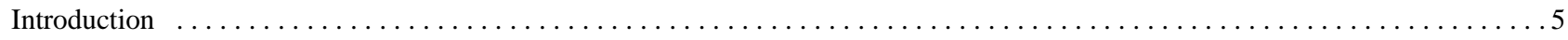

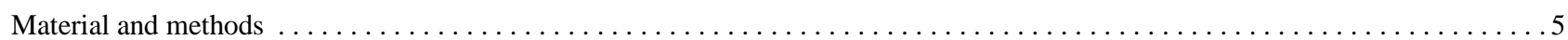

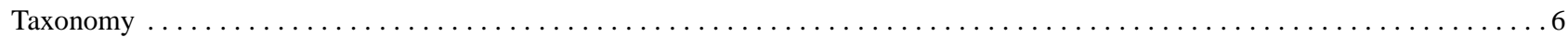

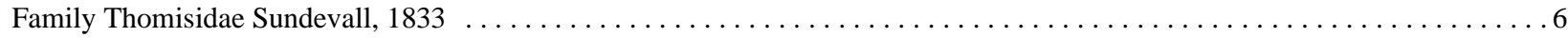

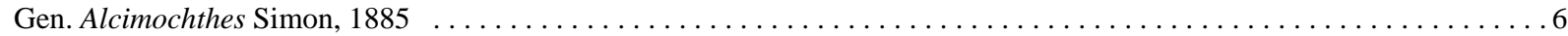

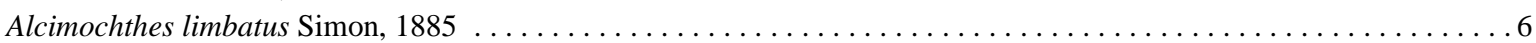

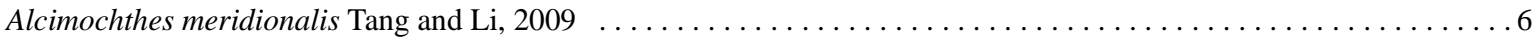

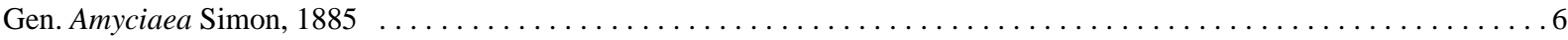

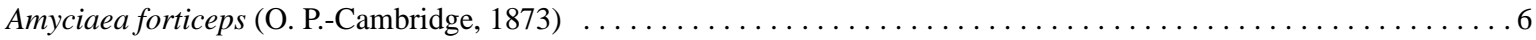

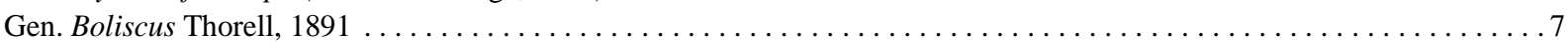

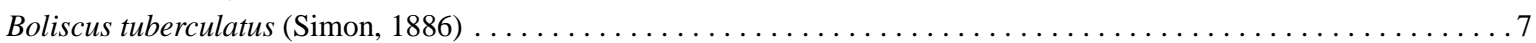

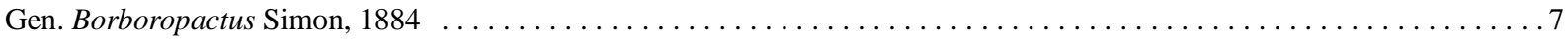

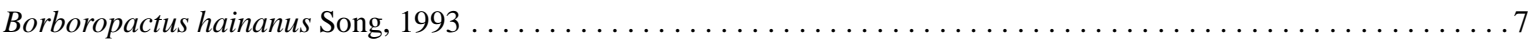

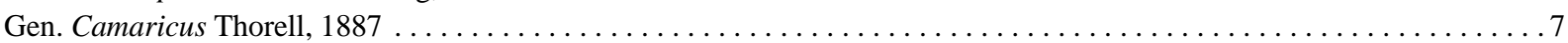

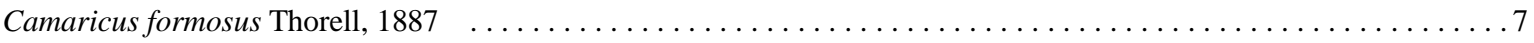

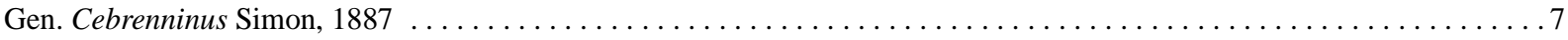

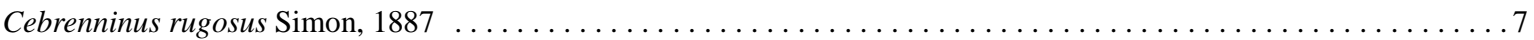

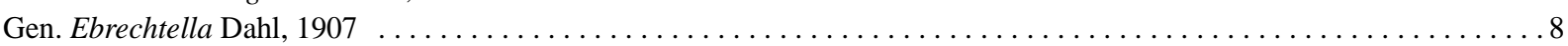

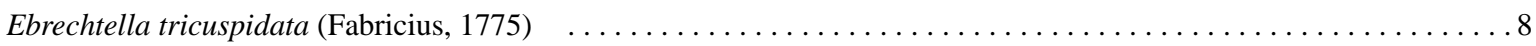

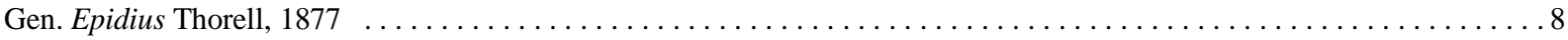

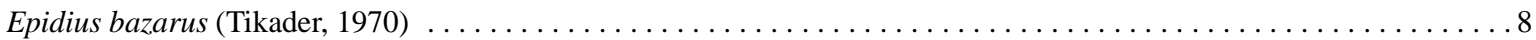

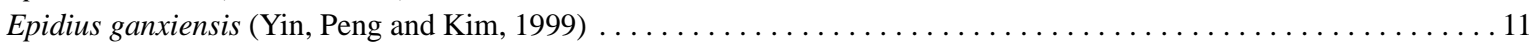

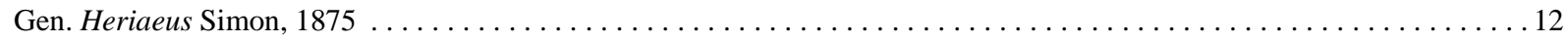

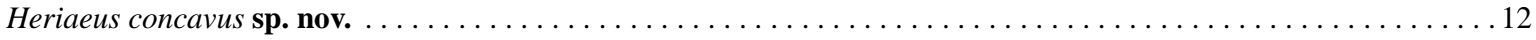

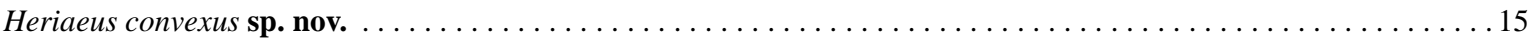

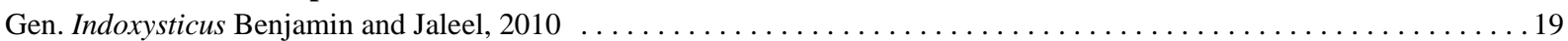

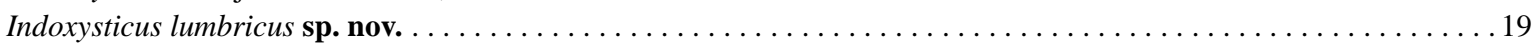

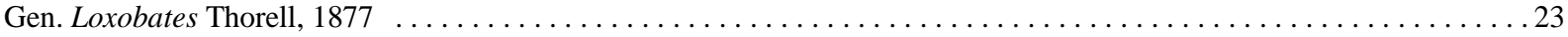

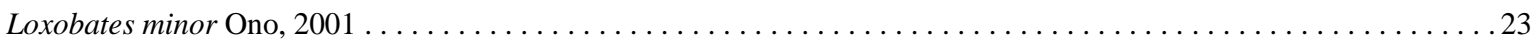

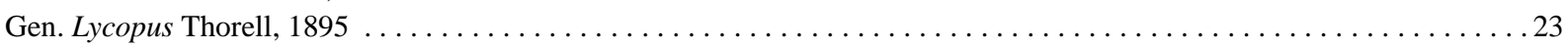

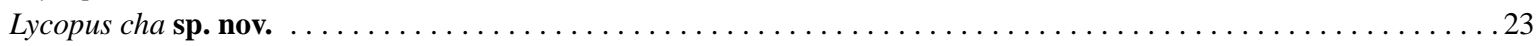

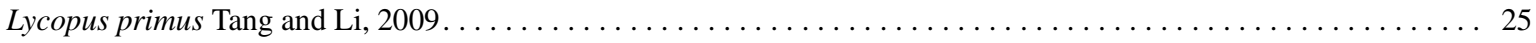

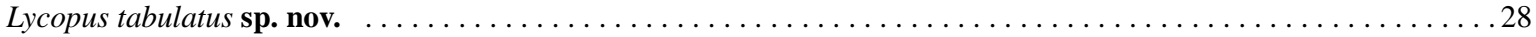

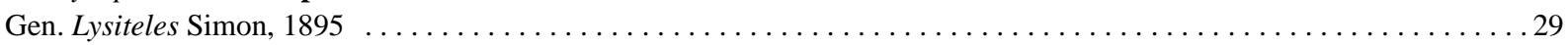

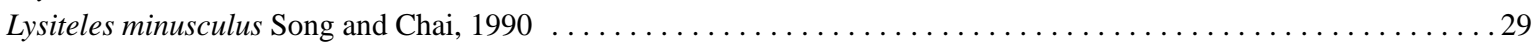

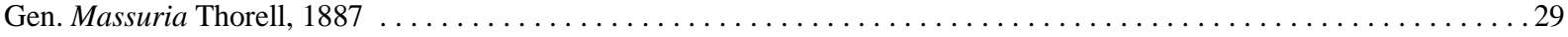

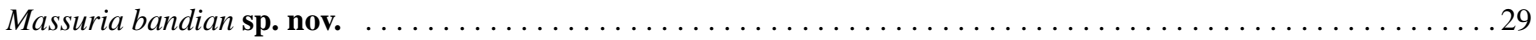

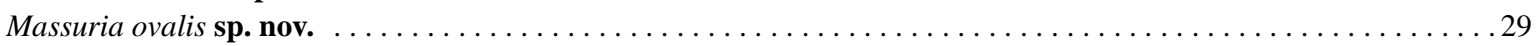

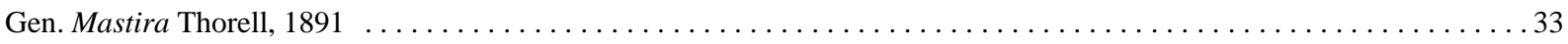

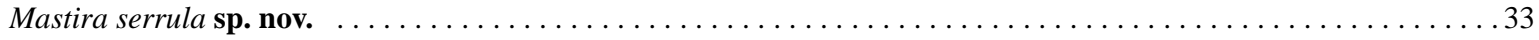

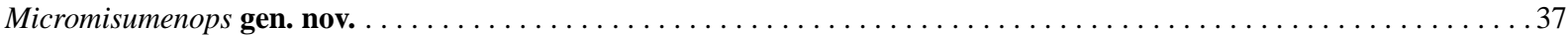

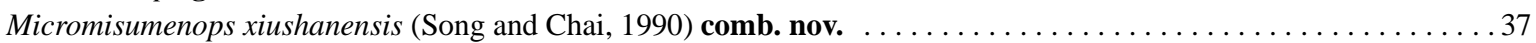

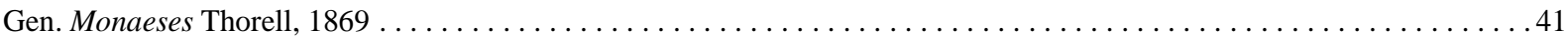

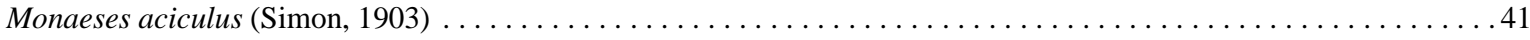

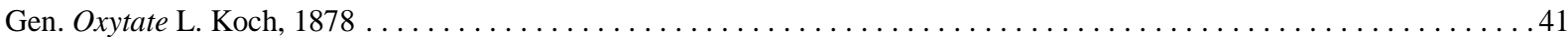

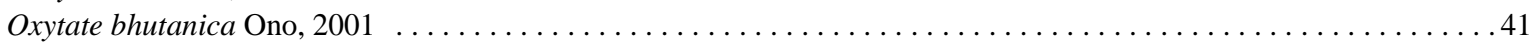

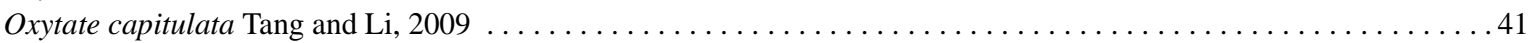

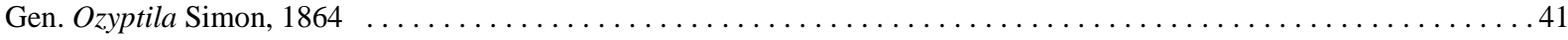

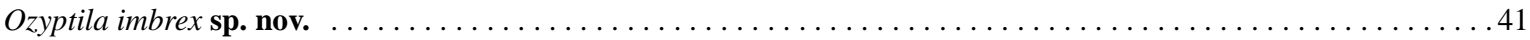

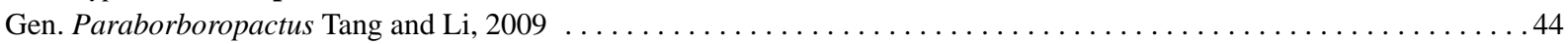

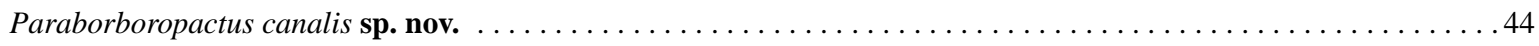

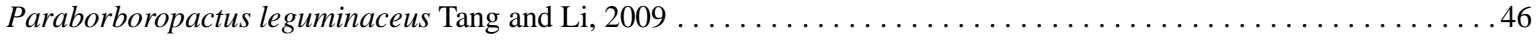

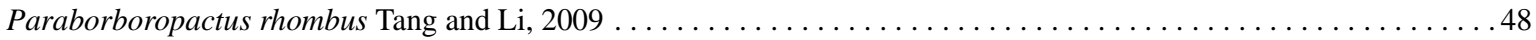

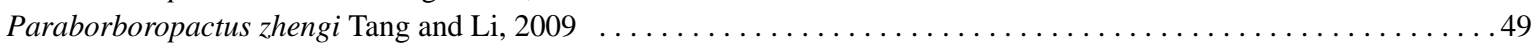

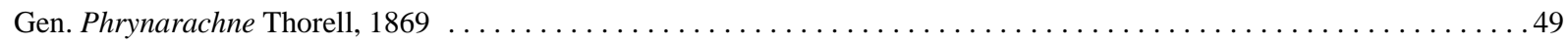

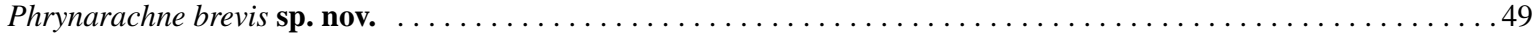

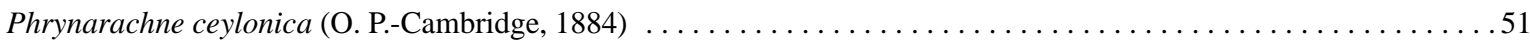

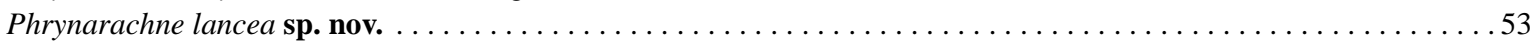




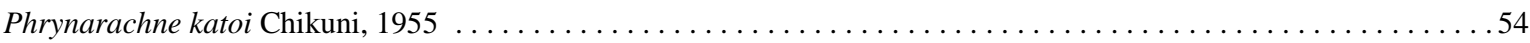

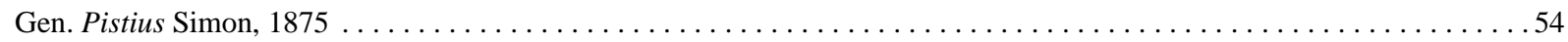

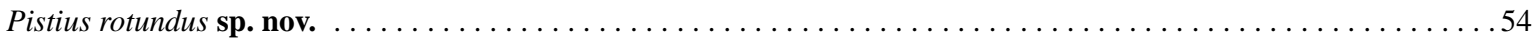

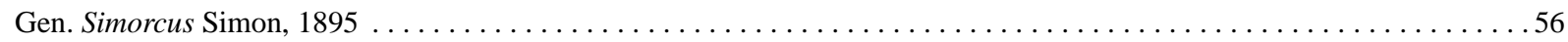

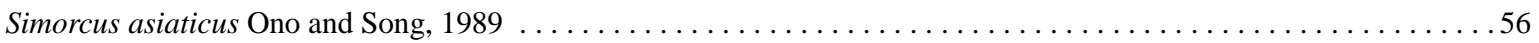

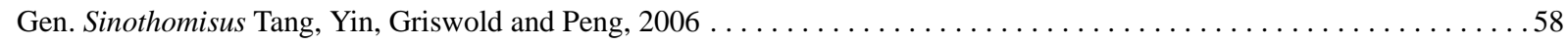

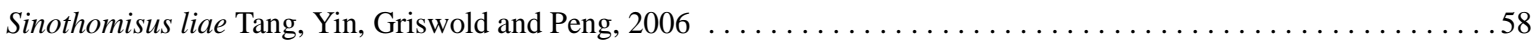

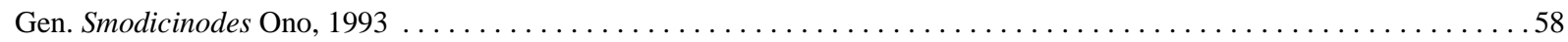

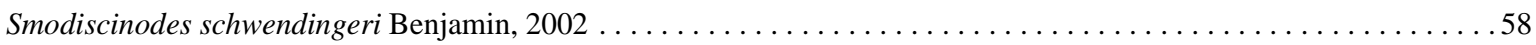

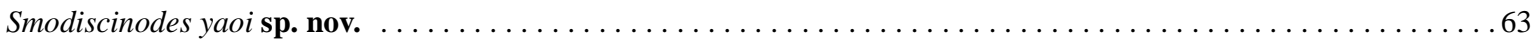

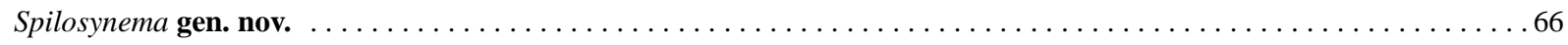

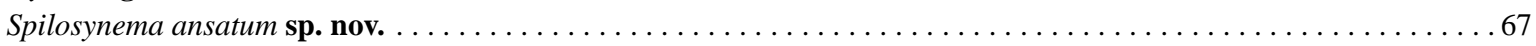

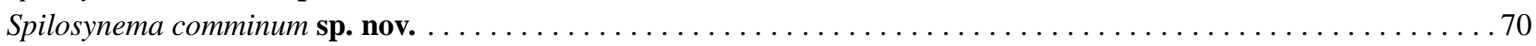

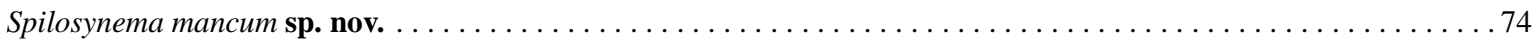

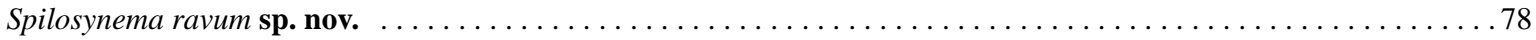

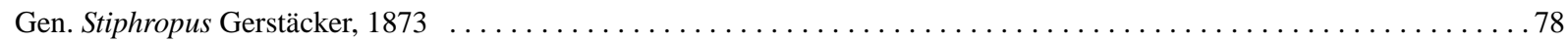

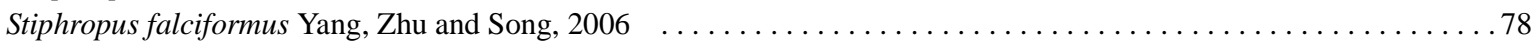

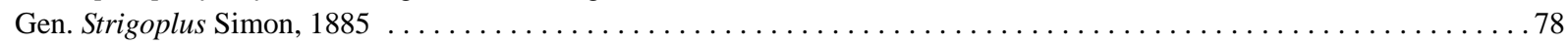

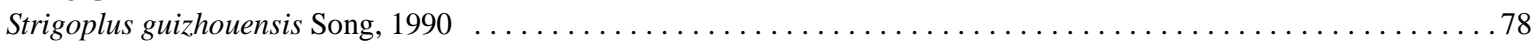

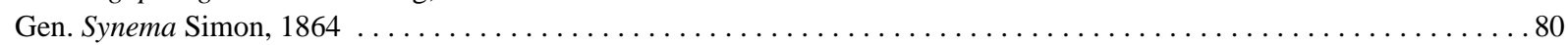

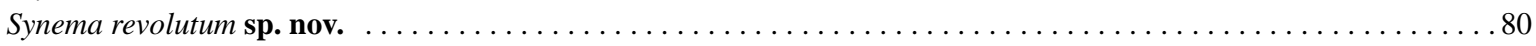

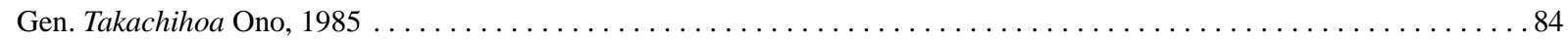

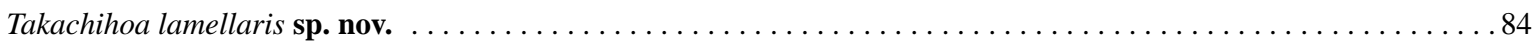

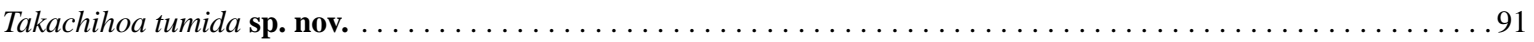

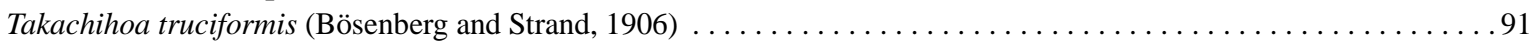

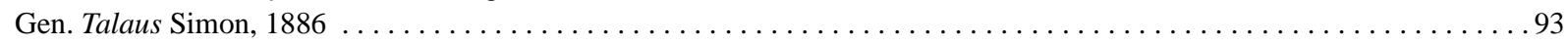

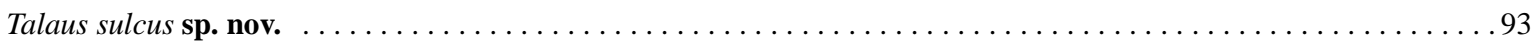

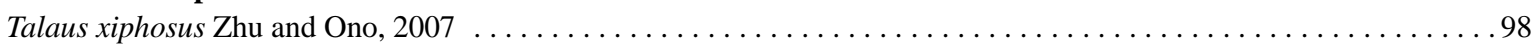

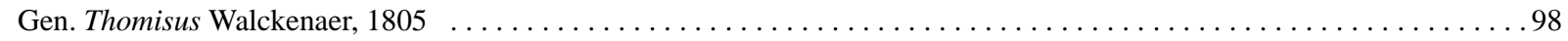

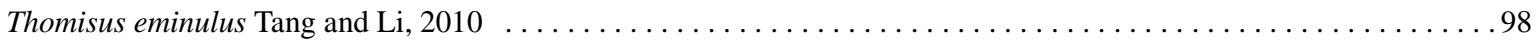

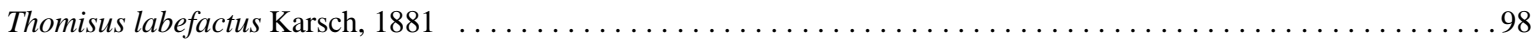

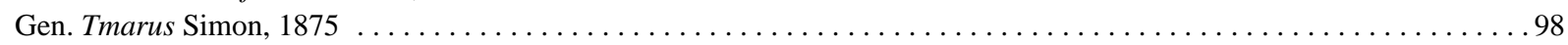

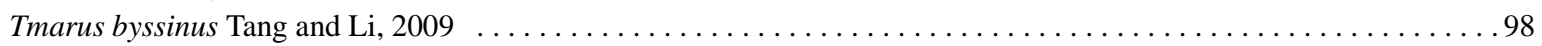

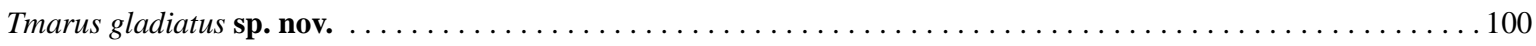

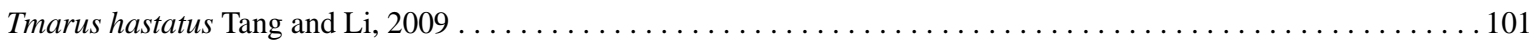

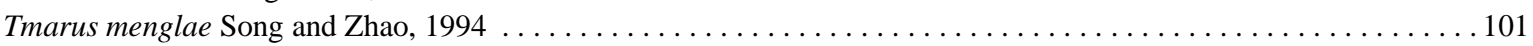

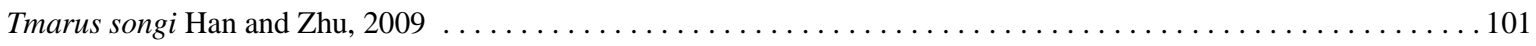

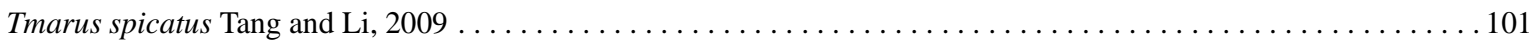

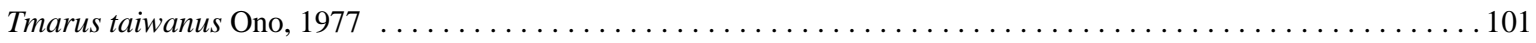

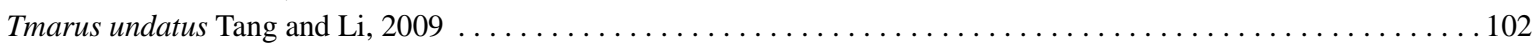

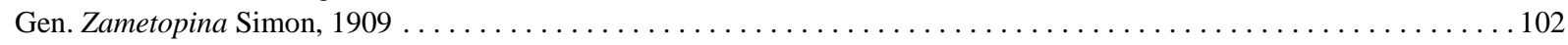

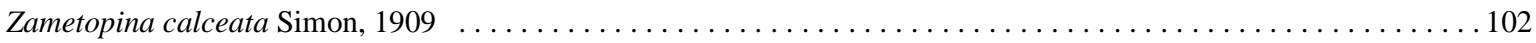

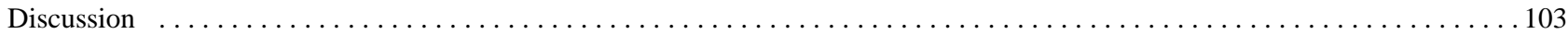

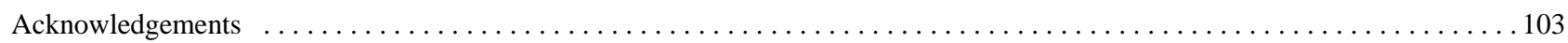

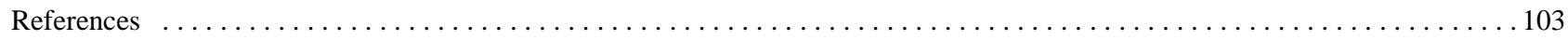

\begin{abstract}
The crab spiders (Araneae: Thomisidae) collected from Xishuangbanna, Yunnan Province, China are studied. A total of 34 genera and 62 species are reported, including 2 new genera and 23 new species: Micromisumenops gen. nov. of the tribe Misumenini Simon, 1895 (type species Misumenops xiushanensis Song and Chai, 1990), Spilosynema gen. nov. of the tribe Talaini Simon, 1895 (type species $S$. ansatum sp. nov.); Heriaeus concavus sp. nov., H. convexus sp. nov., Indoxysticus lumbricus sp. nov., Lycopus cha sp. nov., L. tabulatus sp. nov., Massuria bandian sp. nov., M. ovalis sp. nov., Mastira serrula sp. nov., Ozyptila imbrex sp. nov., Paraborboropactus canalis sp. nov., Phrynarachne brevis sp. nov., $P$. lancea sp. nov., Pistius rotundus sp. nov., Smodicinodes yaoi sp. nov., Spilosynema ansatum sp. nov., S. comminum sp. nov., S. mancum sp. nov., S. ravum sp. nov., Synema revolutum sp. nov., Takachihoa lamellaris sp. nov., T. tumida sp. nov., Talaus sulcus sp. nov., Tmarus gladiatus sp. nov. Male Epidius bazarus (Tikader, 1970), male Paraborboropactus rhombus Tang and Li, 2009, female Smodicinodes schwendingeri Benjamin, 2002 are described for the first time.
\end{abstract}

Key words: Taxonomy, new genus, new species, Southeast Asia, tropical rainforest 


\section{Discussion}

The tropical seasonal rainforest of Xishuangbnana has a high diversity of crab spiders. A total of 62 species in 34 genera (including 2 new genera and 23 new species) were collected from Menglun Natural Reserve, which is only a town of Xishangbanna. The crab spiders were collected mainly by hand searching, pitfall traps and fogging from different kinds of tropical forests, altitude 500-1000 m. Only few crab spiders were collected from rubber tree forests. The dominant species of our collections were: Amyciaea forticeps $(64 \hat{O}, 50$ +) which can also be collected

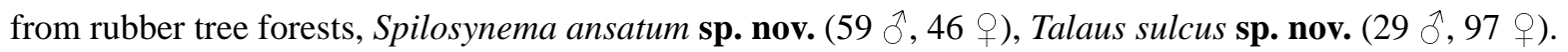

The study revealed a wide distribution of some thomisids in Southeast Asia, e.g., Smodiscinodes schwendingeri, originally recorded from North Thailand; Epidius bazarus, recorded firstly from East India. It is remarkable that no specimens of Xysticus C. L. Koch, 1835 were collected from this area, although Xysticus is the most speciose thomisid genus in the world and is common in other provinces of China.

The crab spider fauna of Xishuangbanna shows similarity to that of Hainan Island (43 species in 25 genera, Tang \& Li 2010), which is situated in a distance of approximately $800 \mathrm{~km}$ and also has tropical forests. A total of 18 species were recorded from both areas as follows: Alcimochthes limbatus, A. meridionalis, Amyciaea forticeps, Boliscus tuberculatus, Borboropactus hainanus, Camaricus formosus, Cebrenninus rugosus, Ebrechtella tricuspidatusa, Lycopus primus, Lysiteles minusculus, Simorcus asiaticus, Strigoplus guizhouensis, Takachihoa truciformis, Talaus xiphosus, Thomisus eminulus, Tmarus menglae, T. songi and T. taiwanus.

Some species are still known from one sex only, and further genera, such as Philodamia Thorell, 1894 and Sanmenia Song and Kim, 1992 were only recorded with juveniles and are not included here. We will continue to explore the diversity of crab spider from Xishuangbanna, Yunnan in the future.

\section{Acknowledgements}

The manuscript benefited greatly from comments by Christoph Muster (Putbus, Germany), Yuri M. Marusik (Magadan, Russia), Xinping Wang (www.Amaurobiidae.com, USA), Peter Jäger (Frankfurt am Main, Germany) and two anonymous reviewers. Thanks go to Pekka T. Lehtinen (Turku, Finland) for his comments on Spilosynema gen. nov. The field work was supported by Min Cao, Yuping She, Xiaodong Yang (XTBG, China), Guo Zheng (Shenyang Normal University, China) and Zhi-Yuan Yao (IZCAS, China). Special thanks to the late Prof. Changmin Yin (Hunan Normal University, China) for her scientific advices and supports to the first author. This study was financially supported by the Ministry of Science and Technology of the People's Republic of China (MOST grant no. 2006FY110500) to Shuqiang Li; and the National Natural Sciences Foundation of China (NSFC30970320), the Chinese Postdoctoral Science Foundation (20090450054), the third batch of special support of Chinese Postdoctoral Science Foundation 2010 (No.154) and the Scientific Research Fund of Hunan Provincial Education Department (08C564) to Guo Tang.

\section{References}

Benjamin, S.P. (2002) Smodicinodes schwendingeri sp. n. from Thailand and the first male of Smodicinodes Ono, 1993, with notes on the phylogenetic relationships in the tribe Smodicinini (Araneae: Thomisidae). Revue Suisse de Zoologie, 109, 3-8.

Benjamin, S.P., Dimitrov, D., Gillespie, R.G. \& Hormiga, G. (2008) Family ties: molecular phylogeny of crab spiders (Araneae: Thomisidae). Cladistics, 24, 708-722.

Benjamin, S.P. \& Jaleel, Z. (2010) The genera Haplotmarus Simon, 1909 and Indoxysticus gen. nov.: two enigmatic genera of crab spiders from the oriental region (Araneae: Thomisidae). Revue Suisse de Zoologie, 117, 159-167.

Bösenberg, W. \& Strand, E. (1906) Japanische Spinnen. Abhandlungen der Senckenbergischen Naturforschenden Gesellschaft, 30, 93-422.

Cambridge, O.P.- (1873) On some new genera and species of Araneida. Proceedings of the Zoological Society of London, $1873,112-129$.

Cambridge, O.P.- (1884) On two new genera of spiders. Proceedings of the Zoological Society of London, 1884, 196205. 
Cao, M. \& Zhang, J.H. (1997) Tree species diversity of tropical forest vegetation in Xishuangbanna, SW China. Biodiversity and Conservation, 6, 995-1006.

Chikuni, Y. (1955) Five interesting spiders from Japan highlands. Acta Arachnologica, Tokyo, 14, $29-40$.

Fabricius, J.C. (1775) Systema Entomologiae, Sistens Insectorum Classes, Ordines, Genera, Species, Adiectis, Synonymis, Locis Descriptionibus Observationibus. Korte, Flensburg and Lipsiae, 832 pp. (Araneae, pp. 431-441).

Han, G.X. \& Zhu, M.S. (2009) A new species of the genus Tmarus and discovery of the male Tmarus taiwanus (Araneae: Thomisidae) from China. Entomological News, 119, 459-463.

Jézéquel, J.-F. (1966) Araignées de la savane de Singrobo (Côte d'Ivoire). V.-Note complémentaire sur les Thomisidae. Bulletin du Museum D'Histoire Naturelle, Paris, 37, 613-630.

Karsch, F. (1881) Diagnoses Arachnoidarum Japoniae. Berliner entomologische Zeitschrift, 25, 35-40.

Kou, Z.T. \& Zhang, H. (1987) A herpetological report of Xishuangbanna. In: Xu, Y.C., Jiang, H.Q. \& Quan, F. (Eds.). Proceedings of Synthetical Investigation of Xishuangbanna Nature Reserves. Yunnan Science and Technology Press, Kunming, pp. 350-368 [in Chinese].

Lehtinen, P.T. (2005) Taxonomic notes on the Misumenini (Araneae: Thomisidae: Thomisinae), primarily from the Palaearctic and Oriental regions. In: Logunov, D.V. \& Penney D. (Eds.), European Arachnology 2003 (Proceedings of the 21st European Colloquium of Arachnology, St.-Petersburg, 4-9 August 2003). Arthropoda Selecta, Special Issue, 1, 147-184.

Lehtinen, P.T. \& Marusik, Y.M. (2008) A redefinition of Misumenops F. O. Pickard-Cambridge, 1900 (Araneae, Thomisidae) and review of the New World species. Bulletin of the British Arachnological Society, 14, $173-198$.

Li, H.M, Ma, Y.X., Liu, W.J \& Cao, M. (2007) Demand for rubber is causing the loss of high diversity rain forest in SW China. Biodiversity and Conservation, 16, 1731-1745.

Li, S. \& Wang, X.P. (2010) Endemic spiders in China. Available from: http://www.ChineseSpecies.com (accessed 30 June 2010).

Li, Z.X., Zhou, Y.F. \& Yang, Z.Z. (2009) First description of the female of Stiphropus falciformus (Araneae: Thomisidae). Acta Arachnologica, Tokyo, 58, 65-66.

Loerbroks, A. (1983) Revision der Krabbenspinnen-Gattung Heriaeus Simon (Arachnida: Araneae: Thomisidae). Verhandlungen des Naturwissenschaftlichen Vereins zu Hamburg, 26, 85-139.

Myers, N., Mittermeier, R.A., Mittermeier, C.G., Dafonseca, G.A.B. \& Kent, J. (2000) Biodiversity hotspots and conservation priorities. Nature, 403, 853-858.

Ono, H. (1977) Thomisidae aus Japan I. Das Genus Tmarus Simon (Arachnida: Araneae). Acta Arachnologica, Tokyo, 27 (Spec. No.), 61-84.

Ono, H. (1984) The Thomisidae of Japan IV. Boliscus Thorell, 1891 (Arachnida, Araneae), a genus new to the Japanese fauna. Bulletin of the National Science Museum, Series A (Zoology), 10, 63-71.

Ono, H. (1988) A Revisional Study of the Spider Family Thomisidae (Arachnida, Araneae) of Japan. National Science Museum, Tokyo, $252 \mathrm{pp}$.

Ono, H. (2001) Crab spiders of the family Thomisidae from the Kingdom of Bhutan (Arachnida, Araneae). Entomologica Basiliensia, 23, 203-236.

Ono, H. (2002) New species of crab spiders (Araneae, Thomisidae) from Japan. Bulletin of the National Science Museum, Series A (Zoology), 28, 201-210.

Ono, H. \& Song, D.X. (1989) Discovery of the strophiine genus Simorcus (Araneae: Thomisidae) in Asia. In: Nishikawa, Y. \& Ono, H. (Eds.), Arachnological Papers Presented to Takeo Yaginuma on the Occasion of his Retirement. Osaka Arachnologists' Group, Osaka, pp. 117-122.

Platnick, N.I. (2010) The world spider catalog, version 11.0. American Museum of Natural History. Available from: http://research.amnh.org/entomology/spiders/catalog/index.html (accessed 30 July 2010).

Sen, S., Saha, S. \& Raychaudhuri, D. (2010) A new spider genus of the tribe Smodicinini (Araneae: Thomisidae) from India. Munis Entomology \& Zoology, 5, 344-349.

Simon, E. (1886) Arachnides recuellis par M. A. Pavie (sous chef du service des postes au Cambodge) dans le royaume de Siam, au Cambodge et en Cochinchine. Actes de la Société linnéenne de Bordeaux, 40, 137-166.

Simon, E. (1887). Espèces et genres nouveaux de la famille des Sparassidae. Bulletin de la Société zoologique de France, $12,466-474$.

Simon, E. (1895) Histoire naturelle des araignées. Roret, Paris, 1, 761-1084.

Simon, E. (1897) Histoire naturelle des araignées. Roret, Paris, 2, 1-192.

Simon, E. (1903). Etudes arachnologiques. 33e Mémoire. LIII. Arachnides recueillis à Phuc-Son (Annam) par M. H. Fruhstorfer (nov-dec. 1899). Annales de la Société entomologique de France, 71, 725-736.

Simon, E. (1909). Étude sur les Arachnides du Tonkin ( $1^{\text {ere }}$ partie). Bulletin scientifique de la France et de la Belgique, $42,69-147$.

Song, D.X. (1993) A new species of Thomisidae from China (Araneae). Sinozool, 10, 89-91.

Song, D.X. \& Chai, J.Y. (1990) Notes of some species of the family Thomisidae (Arachnida: Araneae) from Wuling Shan area. In: Zhao, E.M. (Ed.), From Water onto Land. C.S.S.A.R., Beijing, pp. 364-374. 
Song, D.X. \& Zhao, J.Z. (1994) Four new species of crab spiders from China. Acta Arachnologica Sinica, 3, $113-118$.

Song, D.X. \& Zhu, M.S. (1997) Fauna Sinica: Arachnida: Araneae: Thomisidae, Philodromidae. Science Press, Beijing, $259 \mathrm{pp}$.

Tang, G., Blick, T. \& Ono, H. (2010) Rediscovery of an obscure spider genus Zametopina Simon, 1909 (Araneae, Thomisidae) from Yunnan, China. Bulletin of the National Science Museum, Series A (Zoology), 36, 65-70.

Tang, G. \& Li, S. (2009a) Three new crab spiders from Xishuangbanna rainforest, southwestern China (Araneae: Thomisidae). Zootaxa, 2109, 45-58.

Tang, G. \& Li, S. (2009b) The crab spiders of the genus Tmarus from Xishuangbanna, Yunnan, China (Araneae: Thomisidae). Zootaxa, 2223, 48-68.

Tang, G. \& Li, S. (2009c) Paraborboropactus gen. nov., with description of 3 new species of crab spiders from Xishuangbanna, Yunnan, China (Araneae: Thomisidae). Acta Zootaxonomica Sinica, 34 , 712-721.

Tang, G. \& Li, S. (2010) Crab spiders from Hainan Island, China (Araneae, Thomisidae). Zootaxa, 2369, 1-68.

Tang, G., Peng, X.J., Ubick, D., Griswold C. \& Yin, C.M. (2008) Four crab spiders of the family Thomisidae (Arachnida: Araneae) from Yunnan, China. Acta Zootaxonomica Sinica, 33, 241-247.

Tang, G., Yin, C.M., Griswold, C. \& Peng, X.J. (2006) Description of Sinothomisus gen. nov. with a new species from Yunnan Province, China (Araneae, Thomisidae). Zootaxa, 1366, 61-68.

Tang, G., Yin, C.M., Peng, X.J., \& Griswold, C. (2009) Six crab spiders of the subfamily Stephanopinae from Southeast Asia (Araneae: Thomisidae). Raffles Bulletin of Zoology, 57, 39-50.

Tang, L.R. \& Song, D.X. (1988) On new species of the family Thomisidae from China (Arachnida: Araneae). Acta Zootaxonomica Sinica, 13, 245-260.

Thorell, T. (1887) Viaggio di L. Fea in Birmania e regioni vicine. II. Primo saggio sui ragni birmani. Annali del Museo civico di storia naturale di Genova, 25, 5-417.

Tikader, B.K. (1970) Spider fauna of Sikkim. Records of the Zoological Survey of India, 64, 1-83.

Wang, Y.X. \& Jin, B. (1987) Mammals in Xishuangbanna area and a brief survey of its fauna. In: Xu, Y.C., Jiang, H.Q. \& Quan, F. (Eds.). Proceedings of Synthetical Investigation of Xishuangbanna Nature Reserves. Yunnan Science and Technology Press, Kunming, pp. 289-304 [In Chinese].

Yang, Y., Xie, T., Duan, Y., Xu, W. \& Zhu, H. (1987) On birds from Xishuangbanna. In: Xu, Y.C., Jiang, H.Q. \& Quan, F. (Eds.). Proceedings of Synthetical Investigation of Xishuangbanna Nature Reserves., Yunnan Science and Technology Press, Kunming, pp. 326-330 [In Chinese].

Yang, Z.Z., Zhu, M.S. \& Song, D.X. (2006). A newly recorded genus from China and two new species of the family Thomisidae. Acta Arachnologica Sinica, 15, 65-69.

Yin, C.M., Peng, X.J. \& Kim, J.P. (1999) Three new species of the genus Philodromus from China (Araneae: Philodromidae). Korean Journal of Biological Sciences, 3, 355-358.

Zhu, M.S. \& Ono, H. (2007) New record of the spider genus Talaus from south China, with description of a new species (Araneae: Thomisidae). Acta Arachnologica, Tokyo, 56, 81-83.

Zhu, M.S. \& Song, D.X. (2006) A new discovery of the male spider and a new record from China (Araneae, Thomisidae). Acta Zootaxonomica Sinica, 31, 549-552. 